\title{
Fostering Knowledge Sharing through Care Culture: A Comparison Study of Membership-Oriented and Service-Oriented NGOs in Malaysia
}

\author{
Nurul Hidayana Mohd Noor, Siti Hajar Abu Bakar Ah, and Mohd Awang Idris
}

\begin{abstract}
The paper aims to examine the influence of care culture (collaboration, trust, and learning) towards knowledge sharing behavior. A purposive sampling and a structured questionnaire survey were employed in approaching 200 social workers from membership-oriented NGOs $(n=100)$ and service-oriented NGOs $(n=100)$ located in Klang Valley area, Malaysia. A multiple regression and an independent sample t-test were used to test the hypotheses. Findings revealed trust $(52.1 \%)$ and collaboration $(\mathbf{2 8 . 5 \%})$ significantly predict knowledge sharing. Despite the fact, learning culture does not appear as a predictor variable, this study also discovered service-oriented NGOs have a high level of trust, collaboration, learning, and knowledge sharing as compared to membership-oriented NGOs. The present study contributes to previous literature by providing comparison data of different categories of NGOs.
\end{abstract}

Index Terms-Care culture, knowledge sharing, service-oriented NGOs, membership-oriented NGOs.

\section{INTRODUCTION}

Throughout the world, there has been a massive proliferation of Non-Governmental Organizations (NGOs). Unlike public and private organizations, NGOs operate within an unpredictable environment and need to compete for the resources [1]. For example, the demand and supply for funding, grant, volunteer, and support are always changing over a period. They also need to compete among other NGO's for the resources which can affect their organizational life cycle [2]. Based on the theoretical foundation of the resource-based view, NGOs need to utilize it internal resources in order to remain competitive [3]. In this case, we niche our focus on the utilization of organizational culture and knowledge in helping NGOs to be sustained.

In general, organizational culture refers to the way things are done around organization [4]. In other words, it can be described as the shared behaviors, beliefs, symbols, understandings, and assumptions subscribed by the employees within the organization. A significant amount of

Manuscript received November 24, 2014; revised March 10, 2015. This paper is part of a doctoral work at University of Malaya, Malaysia. The financial supports for the study have been provided by the MARA Technology of University (UiTM), Malaysia and Malaysian Ministry of Education

Nurul Hidayana Mohd Noor and Siti Hajar Abu Bakar Ah are with the Department of Social Justice \& Administration, University of Malaya, 50603 Kuala Lumpur, Malaysia (e-mail: nurulhidayana@yahoo.com, shajar@um.edu.my).

Mohd Awang Idris is with the Department of Anthropology \& Sociology, University of Malaya, 50603 Kuala Lumpur, Malaysia (e-mail: idrma@um.edu.my). scholarly attention has recognized the association between culture and knowledge sharing [5], [6]. Thus, we believe culture acts as imperative factor in enhancing knowledge sharing.

We notice the scarcity of studies on these variables in the context of voluntary organization. Previous studies tend to dictate the subject in the context of public and private organization. This warrants more systematic investigation especially from the perspective of Malaysian NGO. Moreover, the research studies from Eastern perspective are very scant as it has been dominated by Western. Thus, the central aim of the present study is to examine the influence of care culture towards knowledge sharing. In addition, we also seek to compare the level of care culture and knowledge sharing among membership-oriented and service-oriented NGOs due to the differences in the nature of their operation. Perhaps the findings might reveal new knowledge for the current research.

\section{LITERATURE REVIEW}

Nonaka and Takeuchi (1995) categorized knowledge into two types: 1) tacit knowledge (i.e., from the human brain) and 2) explicit knowledge (i.e., context-specific and documented knowledge) [7]. Therefore, it is essential to inculcate the sharing of both tacit and explicit knowledge, because it helps to provide efficient solution to enhance organization ability to exploits the opportunities [8].

Knowledge sharing is a subset of knowledge management [9] and can be defined as "the act of making knowledge available to others within the organization" [10]. A robust of studies has recognized the linkage between organizational culture and knowledge sharing [11]. For example, based on the theory and research's review related to knowledge sharing, Ipe (2003) discovered culture is a key enabler of knowledge sharing [12]. A culture that inculcates knowledge sharing does enable the organization in increasing its competitive edge [13].

For this study, organizational culture is examined based on "care" concept. Care is a vital element of organizational relationship [14]. Organizational that focus on care relationship probably has more effective knowledge sharing. This is because the knowledge is share voluntarily by the employees. In other words, employees work as a team and view the problems together in order to derive for the solutions. In contrast, when the care relationship is low, employees tend to capture the knowledge by themselves and unwilling to share it. They believed sharing the valuable 
knowledge can affect their reputation and position. In an academic jargon, this is known as knowledge hoarding [15].

In this study, we adopted the research model of care culture from Lee and Choi (2003)'s study which recognized three types of care culture: collaboration, trust, and learning [16]. Collaboration can reduce individual differences and build shared understanding among the employees [17]. This is important because knowledge sharing process cannot runs effectively without shared understanding [18]. Simons, Vaquez, and Harris (1999) also discovered collaboration is a driver for team inclusiveness and assist the exchange of knowledge within an organization [19].

Next, a number of cultural dimensions have been recognized to affect knowledge sharing, and trust has captivated many scholar attentions. For example, a plethora of studies have revealed the significant influence of trust towards knowledge sharing [20]. Cook and Wall (1980, p. 39) defined trust as "the extent to which one is willing to ascribe good intentions to and have confidence in the words and actions of other people" [21]. Trust helps to create a mutual faith which facilitates knowledge sharing [22]. Davenport and Prusak (2000) determined that knowledge management process will fail without trust [23]. Thus, the organization should emphasize in implementing an environment to enhance trust among employees [24].

Miller (1996) defined learning as the accomplishment of new knowledge, and eager to apply that knowledge in making decisions or persuading others [25]. Learning can improve overall organizational knowledge flow [26]. For example, Taylor and Wright's (2004) study discovered organization that focused on learning, positively associated with active knowledge sharing [27]. Korten (1980) outlined three stages of the effective and efficient learning approach for the NGOs [28]. First, NGOs must consider how a task should be best performed. Second, NGOs must asking questions about how a task can be performed at an acceptable cost. The third is the NGOs must find the ways to increase the impact of its work [28].

In addition, we also aim to provide a comparison data due to the nature of the NGOs that is mainly difference among each other'. NGOs can be divided into various categories depending on their degree of autonomy, setting, and scope of activities [29]-[31]. A simple way to classify NGOs is to focus on their primary objectives and functions. In this respect, we followed the categorization developed by Ebrahim (2003) which we focused on the two main categories (i.e., service and membership) [32]. He elaborates membership NGOs primarily focused on the interest of their members (e.g., employment association and sport club). The main source of funding is from profit-oriented activities such as membership fees and sales, and their main focus is on the benefits of their members. Whereas, service NGOs are largely focus on a range of services to their clients or beneficiaries (e.g., World Vision and Mercy Malaysia).

The main source of funding is from nonprofit-oriented activities such as donation and grant. Their main activity mostly focuses on the targeted public [32]. Recognizing these differences, this study provides new insight to the current research by comparing the level of care culture and knowledge sharing among membership-oriented and service-oriented NGOs. Therefore, based on the brief discussion, this study proposes the following hypotheses:

H1: Collaboration culture significantly predicts knowledge sharing

H2: Trust culture significantly predicts knowledge sharing

H3: Learning culture significantly predicts knowledge sharing

H4: Service-oriented NGOs have a high level of collaboration culture than membership-oriented NGOs

H5: Service-oriented NGOs have a high level of trust culture than membership-oriented NGOs

H6: Service-oriented NGOs have a high level of learning culture than membership-oriented NGOs

H7: Service-oriented NGOs have a high level of knowledge sharing than membership-oriented NGOs

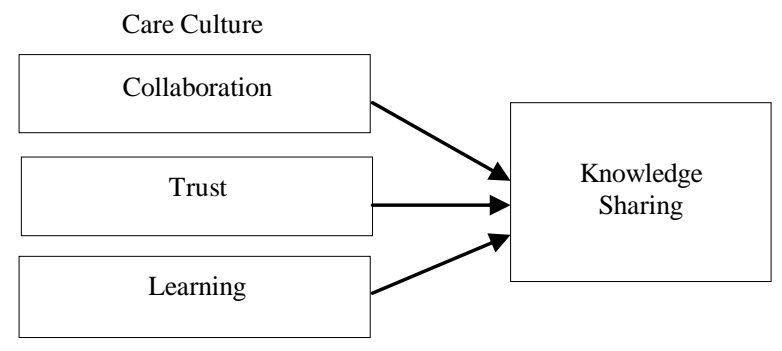

Fig. 1. Research model.

\section{Research Methodology}

\section{A. Data Collection and Participants}

The study employed a self-administered questionnaire. The population of this study is social worker who representing membership-oriented and service-oriented NGOs located in Klang Valley area. This study niches its focus in this area due to a large number of registered NGO [33]. Klang Valley is an area in Malaysia comprising the area in central Selangor, including Kuala Lumpur and its surroundings (see Fig. 2).

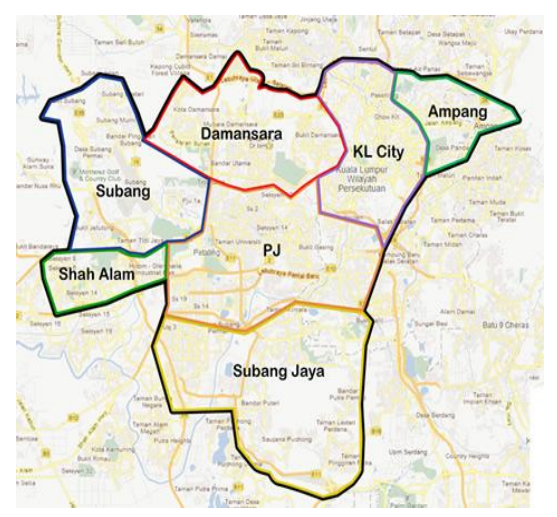

Fig. 2. Klang valley area.

For the comparison purpose, the distribution of the respondents was selected using a purposive sampling. Out of the 200 selected social workers; 50\% were membership-oriented NGOs and another 50\% were service-oriented NGOs. A majority of studies preferred sample sizes of 100 to 400 for purposes of testing hypotheses 
[34]. Table I summarizes the demographic profile of the respondents. In term of composition of the sample, $50 \%$ of the respondents were male, and $50 \%$ of them were female. Most $78 \%$ of the respondents were Malay and the rest $22 \%$ were non-Malay. Next, $77.5 \%$ respondents were Muslim and the rest were non-Muslim $(22.5 \%)$. More than half of the respondents' age was $\geq 30(83 \%)$ whereas the rest were $<30$ (28.5\%). Among the respondents, 54.9\% attained undergraduate qualifications, and followed by postgraduate qualifications, at $15 \%$ and others qualifications, at $2 \%$. $55.5 \%$ of the respondents had income of $\leq \mathrm{RM} 3000$ and about $44.5 \%$ had income > RM3000. In term of the employment status, $86 \%$ respondents were employees (i.e., full-time), and $14 \%$ were volunteers (i.e., part-time).

TABLE I: PROFILE OF THE RESPONDENTS $(N=200)$

\begin{tabular}{|c|c|c|}
\hline Profile & Frequency & $\%$ \\
\hline \multicolumn{3}{|l|}{ Category } \\
\hline Membership-oriented & 100 & 50.0 \\
\hline Service-oriented & 100 & 50.0 \\
\hline \multicolumn{3}{|l|}{ Gender } \\
\hline Male & 100 & 50.0 \\
\hline Female & 100 & 50.0 \\
\hline \multicolumn{3}{|l|}{ Race } \\
\hline Malay & 156 & 78.0 \\
\hline Non-Malay & 44 & 22.0 \\
\hline \multicolumn{3}{|l|}{ Religion } \\
\hline Muslim & 155 & 77.5 \\
\hline Non-Muslim & 45 & 22.5 \\
\hline \multicolumn{3}{|l|}{ Age } \\
\hline$<30$ & 57 & 28.5 \\
\hline$\geq 30$ & 143 & 83.0 \\
\hline \multicolumn{3}{|l|}{ Highest Academic } \\
\hline \multicolumn{3}{|l|}{ Qualification } \\
\hline Undergraduate & 166 & 54.9 \\
\hline Postgraduate & 30 & 15.0 \\
\hline Others & 4 & 2.0 \\
\hline \multicolumn{3}{|l|}{ Income Group Average } \\
\hline$\leq \mathrm{RM} 3000$ & 111 & 55.5 \\
\hline > RM3000 & 89 & 44.5 \\
\hline \multicolumn{3}{|l|}{ Employment Category } \\
\hline Employee & 172 & 86.0 \\
\hline Volunteer & 28 & 14.0 \\
\hline
\end{tabular}

\section{B. Measurement}

Survey items were adopted based on the established framework (see Table II). The self-administered questionnaire consisted of three parts. The first part comprised of questions on the demographic information. Second part consists of care culture measure; collaboration (5 items), trust (6 items), and learning ( 5 items). The items were adopted from Lee and Choi (2003)'s study [16]. In the final part, the respondents were asked to evaluate their level of knowledge sharing. Established scale developed by van den Hooff and de Ridder (2004) was used [6].

For validity, a principal component analysis was conducted. Hair, Anderson, Tatham, and Black (1998) suggested that items with loading greater than 0.30 is considered significant, loading greater than 0.40 more important, and loading 0.50 or greater are very significant
[35]. For this study, the items with loading of 0.50 or greater were accepted. Furthermore, Cronbach's alpha was computed to examine the reliability. The $\alpha$ reliability for the scales ranged from .78 to .86 , indicating an overall higher reliability factor [36].

TABLE II: OPERATIONALIZATION OF THE CONSTRUCTS

\begin{tabular}{|c|c|c|c|}
\hline Construct & Operational Definition & Item & Source \\
\hline Collaboration & $\begin{array}{l}\text { The degree to which people } \\
\text { in a group actively help one } \\
\text { another in their work }\end{array}$ & 5 & $\begin{array}{l}\text { Lee and } \\
\text { Choi } \\
(2003)[16\end{array}$ \\
\hline Trust & $\begin{array}{l}\text { Maintaining reciprocal } \\
\text { faith in each other in terms } \\
\text { of intention and behaviors }\end{array}$ & 6 & \\
\hline Learning & $\begin{array}{l}\text { Individual own an adaptive } \\
\text { response pattern, in that } \\
\text { they persist, increase effort, } \\
\text { partake in solution-oriented } \\
\text { self-instruction, and claim } \\
\text { to appreciate the challenge }\end{array}$ & 5 & \\
\hline $\begin{array}{l}\text { Knowledge } \\
\text { Sharing }\end{array}$ & $\begin{array}{l}\text { A way of transmitting } \\
\text { knowledge to other } \\
\text { employees who need that } \\
\text { knowledge in the } \\
\text { organization } \\
\text { An individual collect } \\
\text { intellectual capital by } \\
\text { talking to other employees }\end{array}$ & 10 & $\begin{array}{l}\text { Van den } \\
\text { Hooff \& de } \\
\text { Ridder } \\
\text { (2004) [6] }\end{array}$ \\
\hline
\end{tabular}

Note: $N=200$; Five-point scale was used with 1=Strongly Disagree, 2=Disagree, 3=Neutral, 4=Agree, 5=Strongly Agree.

\section{Data Analysis}

A self-reported data and cross-sectional study may cause systematic measurement error [37]. Thus, the Harman test was conducted prior testing the hypotheses. A multiple regression analysis and an independent t-test were carried out for further analysis. The regression analysis was conducted to examine the relationship between care culture and knowledge sharing. An independent t-test was to explore whether those variables were related to the category differences.

\section{RESUlTS}

The result of Harman test indicated that four factors with eigenvalues above 1 were extracted. Of all the variance $66.2 \%$ was explained by these four factors, and the first factors accounted for $32.10 \%$ (see Table III). Since single factor does not appear, common method variance is not a major threat for the current data [37]. After rotation, ten items loaded onto Factor 1 (ranged from 0.773 to 0.887 ). These items all related to the knowledge sharing. On Factor 2, five items were used to measure learning culture loaded satisfactorily (ranged from 0.886 to 0.902 ). Next, on Factor 3, all five items were to measure collaboration culture loaded satisfactorily (ranged from 0.816 to 0.877 ). Finally, on Factor 4 , all six items were used to measure trust culture loaded satisfactorily (ranged from 0.677 to 0.763 ). Not a single factor had been dropped out under this circumstance which means the factor analysis ran on an ultimate success [35]. 
TABLE III: ROTATED SOLUTION FOR OVERALL PRINCIPAL COMPONENT ANALYSIS

\begin{tabular}{|c|c|c|c|c|}
\hline & \multicolumn{4}{|c|}{ Factor } \\
\hline & 1 & 2 & 3 & 4 \\
\hline Collaboration1 & & & .872 & \\
\hline Collaboration2 & & & .860 & \\
\hline Collaboration 3 & & & .877 & \\
\hline Collaboration 4 & & & .862 & \\
\hline Collaboration5 & & & .816 & \\
\hline Trust1 & & & & 677 \\
\hline Trust2 & & & & .729 \\
\hline Trust3 & & & & .754 \\
\hline Trust4 & & & & .755 \\
\hline Trust5 & & & & .754 \\
\hline Trust6 & & & & .763 \\
\hline Learning1 & & .902 & & \\
\hline Learning2 & & .892 & & \\
\hline Learning3 & & .886 & & \\
\hline Learning4 & & .895 & & \\
\hline Learning 5 & & .888 & & \\
\hline Knowledge1 & .858 & & & \\
\hline Knowledge2 & .773 & & & \\
\hline Knowledge3 & .835 & & & \\
\hline Knowledge4 & .797 & & & \\
\hline Knowledge5 & .787 & & & \\
\hline Knowledge6 & .820 & & & \\
\hline Knowledge7 & .788 & & & \\
\hline Knowledge8 & .801 & & & \\
\hline Knowledge9 & .810 & & & \\
\hline Knowledge 10 & .887 & & & \\
\hline Eigenvalues & 17.21 & 2.96 & 2.13 & 1.08 \\
\hline $\begin{array}{l}\text { Total Variance } \\
\text { Explained }\end{array}$ & 8.35 & 5.64 & 4.87 & 4.52 \\
\hline $\begin{array}{l}\text { Percentage of } \\
\text { Variance }\end{array}$ & 32.10 & 21.70 & 18.72 & 17.37 \\
\hline $\begin{array}{l}\text { KMO Measure of } \\
\text { Sampling } \\
\text { Adequency }\end{array}$ & & 0.933 & & \\
\hline $\begin{array}{l}\text { Bartlett's Test of } \\
\text { Sphericity }\end{array}$ & $\begin{array}{l}\text { Approx. } \\
\text { Chi } \\
\text { Square }\end{array}$ & 10427.84 & & \\
\hline & df & 325 & & \\
\hline & Sig. & 0.000 & & \\
\hline
\end{tabular}

Note: $N=200$; Factor loadings $>.50$

Correlation analysis was conducted to establish the relationships among the variables. All variables were positive significantly correlated among each other's (see Table IV) [35].

A multiple regression was conducted to examine the relationship between knowledge sharing and care culture as potential predictors. The three predictor account for $60 \%$ of the variance in knowledge sharing, $R^{2}=.60, F(3,196)=98.19$, $p<.001$ (see Table V). Collaboration $(\beta=.285, p<.001)$ and trust $(\beta=.521, p<.001)$ were positively significant with the criterion. The findings indicate that those NGOs with these types of care culture able to facilitate knowledge sharing among their social workers. Therefore, $\mathrm{H} 1$ and $\mathrm{H} 2$ were accepted. As not expected, only learning culture $(\beta=.023$, $p>0.05)$ was not significantly predicts knowledge sharing. Thus, H3 was rejected.

Finally, an independent t-test was conducted to compare the study variables for membership-oriented and service-oriented NGOs. Based on the results, there was a significant difference in the level of care culture (collaboration, trust, learning) and knowledge sharing among membership-oriented NGOs and service-oriented NGOs (see Table VI).

TABLE IV: MEAN, STANDARD DEVIATION AND CORRELATIONS AMONG VARIABLE

\begin{tabular}{|c|c|c|c|c|c|c|}
\hline Variable & M & SD & 1 & 2 & 3 & 4 \\
\hline Collaboration & 3.62 & 1.25 & 1 & & & \\
\hline Trust & 3.72 & 1.33 & $\begin{array}{l}.60 * \\
*\end{array}$ & 1 & & \\
\hline Learning & 3.97 & .93 & $\begin{array}{l}.45^{*} \\
*\end{array}$ & $\begin{array}{l}.75^{*} \\
*\end{array}$ & 1 & \\
\hline Knowledge Sharing & 3.62 & 1.24 & $\begin{array}{l}.63^{*} \\
*\end{array}$ & $\begin{array}{l}.74 * \\
*\end{array}$ & $\begin{array}{l}.57 * \\
*\end{array}$ & 1 \\
\hline
\end{tabular}

Note: $N=200 ; \quad \mathrm{M}=$ Mean; $\mathrm{SD}=$ Standard Deviation, $* *$ Correlations is significant at the 0.01 level (two-tailed).

TABLE V: REGRESSION ANALYSIS

\begin{tabular}{|c|c|c|c|c|c|c|}
\hline Regression Path & \multicolumn{3}{|c|}{$\begin{array}{l}\text { Unstandardized } \\
\text { Coefficients }\end{array}$} & \multicolumn{3}{|c|}{$\begin{array}{l}\text { Standardized } \\
\text { Beta }\end{array}$} \\
\hline & Beta & \multicolumn{3}{|c|}{ Std. Error } & & \\
\hline Collaboration & $.285 * * *$ & \multicolumn{2}{|c|}{.056} & \multicolumn{2}{|c|}{.285} & \\
\hline Trust & $.521 * * *$ & \multicolumn{2}{|c|}{.072} & \multicolumn{2}{|c|}{.556} & \\
\hline Learning & .023 & \multicolumn{2}{|c|}{.092} & \multicolumn{2}{|c|}{.017} & \\
\hline$R^{2}$ & \multicolumn{3}{|l|}{.600} & & & \\
\hline $\mathrm{F}$ & \multicolumn{3}{|l|}{98.19} & & & \\
\hline$p$ & \multicolumn{3}{|l|}{.000} & & & \\
\hline \multicolumn{7}{|c|}{ Note: $N=200 ; * * * p<0.001$} \\
\hline \multicolumn{7}{|c|}{ TABLE VI: INDEPENDENT T-TEST } \\
\hline \multirow[t]{2}{*}{ Variable } & \multicolumn{2}{|c|}{ Membership } & \multicolumn{2}{|c|}{ Service } & & \\
\hline & M & SD & M & SD & $t$ & $p$ \\
\hline Collaboration & 3.31 & 1.37 & 3.93 & 1.04 & $\begin{array}{l}-3.6 \\
5\end{array}$ & .000 \\
\hline Trust & 3.35 & 1.56 & 4.09 & .91 & $\begin{array}{l}-4.1 \\
3\end{array}$ & .000 \\
\hline Learning & 3.78 & .96 & 4.15 & .88 & $\begin{array}{l}-2.8 \\
2\end{array}$ & .005 \\
\hline Knowledge Sharing & 3.26 & 1.43 & 3.98 & .89 & $\begin{array}{l}-4.2 \\
4 \\
\end{array}$ & .000 \\
\hline
\end{tabular}

First, service-oriented NGOs (M=3.93, SD=1.04) reported significantly higher level of collaboration culture than membership-oriented NGOs $(\mathrm{M}=3.31, \mathrm{SD}=1.37), t(198)=$ $-3.65, p<.001$. Second, service-oriented NGOs $(\mathrm{M}=4.09$, $\mathrm{SD}=.91)$ reported significantly higher level of trust culture than membership-oriented NGOs $(\mathrm{M}=3.35, \mathrm{SD}=1.56)$, $t(198)=-4.13, p<.001$. Third, service-oriented NGOs $(\mathrm{M}=$ $4.15, \mathrm{SD}=.88$ ) reported significantly higher levels of learning than membership-oriented NGOs $(\mathrm{M}=3.78, \quad \mathrm{SD}=.96)$, $t(198)=-2.82, \quad p<.001$. Finally, service-oriented NGOs $(\mathrm{M}=3.98, \mathrm{SD}=.89)$ also reported significantly higher level of knowledge sharing than membership-oriented NGOs $(\mathrm{M}=3.26, \mathrm{SD}=1.43), t(198)=-4.24, p<.001$. Therefore, H4, $\mathrm{H} 5, \mathrm{H} 6$, and $\mathrm{H} 7$ were accepted.

\section{DISCUSSION}

The results showed collaboration and trust culture predict 
knowledge sharing. A body of knowledge believed that trust and collaboration could be considered as the important enablers for knowledge sharing [38]-[41]. In this study, trust culture is the strongest predictor to knowledge sharing. Thus, trust culture acts as the central care culture. The findings are consistent with Lopez, Peon, and Ordas's (2004) study that revealed trust is an essential element for the creation of new knowledge [42]. One well-known scholar in the management field, Kanter (1993) believed trust is vital in establishing a mutual consensus [43]. Trust also associated with collectivism, rather than individualism [44]. In addition, Mayer, Davies, and Schoorman's (1995) study revealed that trust increases the likelihood that knowledge shared is adequately understood which necessarily important for the exchange of tacit knowledge [45].

In term of collaboration culture, Karia and Ahmad (2000) believed collaboration lead to the effective teamwork [46]. Logically, when two or more parties trust each other's, it will contribute to the active collaboration as they were keen to share resources [47]. The active partnership explains why trust appears as a primary predictor on knowledge sharing [48]. Even though this study discovered learning culture does not significantly predict knowledge sharing, we cannot ignore the role of learning culture as the enabler for knowledge sharing. Lopez, Peon, and Ordas (2004) discovered collaboration culture is a mean for learning [42]. Their study can provide explanation for our results on why learning culture does not significantly contributes to knowledge sharing as its need a strong collaboration culture.

Next, this study also discovered that the level of care culture and knowledge sharing was different between membership-oriented NGOs and service-oriented NGOs. Due to the dynamic nature of the operation, some NGOs utilize it internal resource to gain competitive position. Service-oriented NGOs were found to have a higher level of collaboration, trust, and learning culture as compared to membership-oriented NGOs. Moreover, they were also found to have a higher level of knowledge sharing. Since their main source of funding is from nonprofit-oriented activities such as grant, donation, and private contribution, they need to act more active as compared to membership-oriented NGOs. Moreover, they also need to have a strong culture in order to attract potential volunteers and retain the existing one. In contrast, the nature of membership-oriented NGOs which is more stable, help them to survive in a complex environment. Despite the complexities and differences of the nature among NGOs, all NGOs still need to have a strong culture as it will help them to sustain and ensure smooth operations of the activities and programs.

Thus, as managerial implications, a uniform culture is vital because it contributes to the organizational improvement. The leaders of NGOs need to bear in mind that altering organizational culture requires changing others organizational element such as strategy, operational practices, employee expectations, and physical facilities [49]. Moreover, no single culture is best fit, and a match between culture and situation need to continuously engaged. Management also may needs to help employees to inculcate a strong culture for the effective knowledge sharing [50]. For example, provide training or implement the bonding activities.

\section{CONCLUSION}

This study aims to examine the impact of care culture towards the level of knowledge sharing behavior among social worker. The findings from this study have a number of significant theoretical and managerial implications. To the best of our knowledge, this study makes an original contribution to the existing studies, since we stressed on the influence of care culture on knowledge sharing in the context of voluntary organizations. Based on the syntheses from previous studies, too much focus has been given on public and private organization. Thus, this research produced an empirically tested model from a new perspective. This research also provides an evidence that is specific to knowledge sharing rather than knowledge management, in general. Although our research findings provide valuable information on the roles of care culture in describing knowledge sharing, some limitations should be noted. The current study only conducted in a focused geographic area, Klang Valley. Perhaps further research could generalize the study throughout Malaysia. Using a self-administered survey and a cross-sectional study could have limited our knowledge on the causality effect. Further investigation using mixed method study, multimethod, multilevel or longitudinal research would address these issues. In addition, future research may focus on other critical areas such as knowledge management process, the antecedents of knowledge sharing, the application of the study into different settings, and the comparison study among Eastern and Western context.

\section{APPENDIX: QUESTIONNAIRE ITEMS}

Collaboration:

1) My NGO members are satisfied by the degree of collaboration

2) My NGO members are supportive

3) My NGO members are helpful

4) There is a willingness to collaborate across NGO units within my NGO

5) There is a willingness to accept responsibility for failure Trust:

1) My NGO members are generally trustworthy

2) My NGO members have reciprocal faith in other members' intentions and behaviours

3) My NGO members have reciprocal faith in others' ability

4) My NGO members have reciprocal faith in others' behaviours to work towards organizational goals

5) My NGO members have reciprocal faith in others' decision towards organizational interests than individual interests

6) My NGO members have relationships based on reciprocal faith

Learning:

1) My NGO provides various formal training programs for performance of duties

2) My NGO provides opportunities for informal individual 
development other than formal training such as work assignments and job rotation

3) My NGO encourages people to attend seminars, symposia, and so on

4) My NGO provides various programs such as clubs and community gatherings

5) My NGO members are satisfied by the contents of job training or self-development programs

Knowledge Sharing:

1) When I have learned something new, I find that colleagues in my department can learn it as well

2) I share the information I have with my colleagues within my department

3) I share my skills with my colleagues within my department

4) When I have learned something new, I find to it that colleagues outside my department can learn it as well

5) I share my information with colleagues outside my department

6) I share my skills with colleagues outside my department

7) Colleagues within my department tell me what they know when I ask them about it

8) Colleagues within my department tell me what they skills are when I ask them about it

9) Colleagues outside my department tell me what they know when I ask them about it

10) Colleagues outside my department tell me what they skills are when I ask them about it

\section{ACKNOWLEDGMENT}

We are indebted to the Malaysian Ministry of Education and MARA Technology of University (UiTM) for providing funding for this study.

\section{REFERENCES}

[1] N. Deakin, "The perils of partnership: The Voluntary Sector and The State 1945-1992," in An Introduction to the Voluntary Sector, J. D. Smith, C. Rochester and R. Hedley, Eds. Routledge, London, 1995.

[2] S. Ahmed, "Desired competencies and job duties of non-profit CEOs in relation to the current challenges: Through the lens of CEOs' job advertisements," Journal of Management Development, vol. 24, no. 10 pp. 914-928, 2005.

[3] J. B. Barney, "Organizational culture: Can it be a source of sustained competitive advantage?" Academy of Management Review, vol. 11, no. 3, pp. 656-665, 1986.

[4] K. Blanchard and S. Bowles, Gung Ho, New York: William Morrow and Company, 1998.

[5] C. J. Chen and J. W. Huang, "How organizational climate and structure affect knowledge management: The social interaction perspective," International Journal of Information Management, vol. 27, pp 104-118, 2007.

[6] B. van den Hooff and J. A. de Ridder. "Knowledge sharing in context: The influence of organizational commitment, communication climate and CMC use on knowledge sharing," Journal of Knowledge Management, vol. 8, no. 6, pp. 117-130, 2004.

[7] I. Nonaka and H. Takeuchi, The Knowledge-Creating Company: How Japanese Companies Create the Dynamics of Innovation, New York: Oxford University Press, 1995.

[8] S. O. S. S. Ikhsan and F. Rowland, "Knowledge management in a public organizations in Malaysia: Do people really share?" Journal of Knowledge Management, vol. 8, no. 2, pp. 95-111, 2004.

[9] S. E. Mehrabani and N. A. Mohamad, "Brief review of succession planning and management approach," presented at the 3rd International Conference on Advanced Management Science, Kuala Lumpur, Malaysia, November 4-6, 2011.
[10] M. Abzari and H. Teimouri, "The effective factors on knowledge sharing in organizations," The International Journal of Knowledge, Culture and Change Management, vol. 8, no. 2, pp. 105-13, 2008.

[11] F. Reid, "Creating a knowledge sharing culture among diverse business units," Employment Relations Today, vol. 30, no. 3, pp. 43-49, 2003.

[12] S. L. S. Omar and F. Rowland, "Benchmarking knowledge management in a public organization in Malaysia," An International Journal, vol. 11, no. 3, pp. 238-266, 2004.

[13] S. S. Alam, Z. Abdullah, N. A. Ishak, and Z. M. Zain, "Assessing knowledge sharing behaviour among employees in SMEs: An empirical study," International Business Research, vol. 2, no. 2, pp 115-22, 2009.

[14] M. Ipe, "Knowledge sharing in organizations: a conceptual framework," Human Resource Development Review, vol. 2, no. 4, pp. 337-359, 2003

[15] G. von Krogh, "Care in knowledge creation," California Management Review, vol. 40, no. 3, pp. 133-153, 1998

[16] H. Lee and B. Choi, "Knowledge management enablers, processes, and organizational performance: An integrative view and empirical examination," Journal of Management Information System, vol. 20, pp. 179-228, 2003.

[17] D. L. Barton, Wellsprings of Knowledge: Building and Sustaining the Source of Innovation, Boston: Harvard Business School Press, 1995.

[18] L. Fahey and L. Prusak, "The eleven deadliest sins of knowledge management," California Management Review, vol. 40, no. 3, 1998.

[19] G. F. Simons, C. Vaquez, and P. R. Harris, Transcultural Leadership: Empowering the Diverse Workforce, Houston: Gulf, 1993.

[20] J. Huang and Y. Li, "The mediating effect of knowledge management on social interaction and innovation performance," International Journal of Manpower, vol. 30, no. 3, pp. 285-301, 2009.

[21] J. Cook and T. Wall, "New work attitude measures of trust, organizational commitment and personal need non-fulfilment," Journal of Occupational Psychology, vol. 53, pp. 39-52, 1980.

[22] G. von Krogh and R. Johan, Managing Knowledge. Perspectives on Cooperation and Competition, London: Sage Publication, 1996.

[23] T. H. Davenport and L. Prusak, Working Knowledge: How Organizations Manage What They Know, Boston: Harvard Business School Press, 2000.

[24] F. M. Hsu and C. C. Huang, "Determinants of knowledge transfer performance from cultural perspective in high-tech industry," presented at the Ninth Pacific Asia Conference on Information Systems (PACIS): I.T. and Value Creation, Bangkok, Thailand, 2005.

[25] D. Miller, "A preliminary typology of organizational learning: synthesizing the literature," Journal of Management, vol. 22, pp. 485-505, 1996

[26] V. J. Friedman and W. Overmeer, "Creating Conditions for Organizational Learning," in Handbook of Organizational Learning and Knowledge, M. Dierkes, A. B. Antal, J. Child, and I. Nonaka, Eds. Oxford, Oxford University Press, 2001

[27] W. A. Taylor and G. H. Wright, "Organizational readiness for successful knowledge sharing: Challenges for public sector managers," Information Resources Management Journal, vol. 17, no. 2, pp. 22-37, 2004.

[28] D. C. Korten, "Community organization and rural development: A learning process approach," The Public Administration Review, vol. 40, pp. $480-511,1980$

[29] J. Farrington and D. J. Lewis, Non-Government Organizations and the State in Asia, London: Routledge, 1993.

[30] J. A. Paul, NGOs and Global Policy-Making, New York: Global Policy Forum, United Nations, 2000.

[31] T. Tvedt, Angels of Mercy or Development Diplomats, Oxford: James Curry, 1998.

[32] A. Ebrahim, "Accountability in practice: Mechanisms for NGOs," World Development, vol. 31, no. 5, pp. 813-829, 2003.

[33] Registrar of Society (ROS), Annual Report 2011, Federal State of Putrajaya, Malaysia, Registrar Society of Malaysia, 2012.

[34] E. M. Berman, Essential Statistics for Public Managers and Policy Analysts, 2nd ed. Washington, DC, CQ Press, 2007.

[35] J. F. Hair, R. E. Anderson, R. L. Tatham, and W. C. Black, Multivariate Data Analysis, 5th ed. Upper Saddle Hall: Prentice Hall, 1998.

[36] J. Nunnally, Psychometric Theory, 2nd ed. New York: MacGraw Hill, 1978.

[37] P. M. Podsakoff and D. W. Organ, "Self-reports in organizational research: Problems and prospects," Journal of Management, vol. 12, pp. 69-82, 1986.

[38] H. Aulawi, I. Sudirman, K. Suryadi, and R. Govindaraju, "Literature review towards knowledge enablers which is assumed significantly 
influences KS behavior," Journal of Applied Sciences Research, vol. 5, no. 12, pp. 2262-2270, 2009.

[39] T. H. Davenport and L. Prusak, Working Knowledge: How Organizations Manage What They Know, United States: Harvard Business Press, 1998.

[40] S. Kim and H. Lee, "Organizational factors affecting knowledge sharing capabilities in e-government: An empirical study knowledge management in electronic government," Lectures Notes in Artificial Intelligence, Berlin, vol. 3025, pp. 265-277, 2004.

[41] H. Park, V. Ribiere, and W. D. Schulte, "Critical attributes of organizational culture that promote knowledge management technology implementation success," Journal of Knowledge Management, vol. 8, no. 3, pp. 106-117, 2004

[42] S. P. Lopez, J. M. M. Peon, and C. J. V. Ordas, "Managing knowledge: The link between culture and organizational learning," Journal of Knowledge Management, vol. 8, no. 6, pp. 93-104.

[43] R. M. Kanter, Men and Women of the Corporation, 2nd ed., New York: Basic Books, 1993

[44] J. Wang, M. Ashleigh, and E. Meyer, "Knowledge sharing and team trustworthiness: It's all about social ties," Knowledge Management Research and Practice, vol. 10, no. 2, pp. 57-71, 2006.

[45] R. C. Mayer, J. H. Davies, and F. D. Schoorman, "An integrative model of organizational trust," Academy of Management Review, vol. 20, no. 3, pp. 709-734, 1995

[46] N. Karia and Z. A. Ahmad, "Quality practices that pay: Empowerment and teamwork," Malaysian Management Review, vol. 35, no. 2, pp. 66-76, 2000.

[47] W. Tsai and S. Ghoshal, "Social capital and value creation: The role of intrafirm networks," The Academy of Management Journal, vol. 41, no. 4, pp. 464-476, 1998

[48] R. Cropanzano and M. Mitchell, "Social exchange theory: An interdisciplinary review," Journal of Management, vol. 31, no. 6, pp. $874,2005$.

[49] E. H. Schein, Organizational Culture, Frankfurt/New York: Campus Verlag, 1995

[50] R. M. A. Adaileh and M. S. A. Atawi, "Organizational culture impact on knowledge exchange: Saudi Telecom context," Journal of Knowledge Management, vol. 15, no. 2, pp. 212-230, 2011.

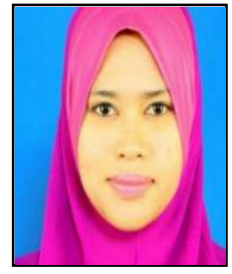

Nurul Hidayana Mohd Noor was born in Butterworth, in the state of Penang, Malaysia, on January 5, 1987. She completed her bachelor's degree in administrative science from Mara Technology of University (UiTM), Malaysia in 2010. She also completed her masters in executive masters of administrative science from the same university in 2012. She has worked as an assistant lecturer at Mara Technology of University (UiTM) from 2010 until 2012 under graduate scheme service. She currently pursues her doctorate study at Department of Social Justice and Administration, Faculty of Arts and Social Science, University of Malaya, Malaysia. Her research interest is third sector, particularly on NGO management, organizational culture, accountability, and knowledge management

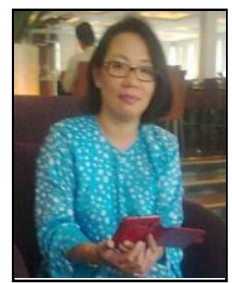

Siti Hajar Abu Bakar Ah is an associate professor at Department of Social Justice and Administration, Faculty of Arts and Social Sciences, University of Malaya, Malaysia. Her research interests include social policy, social work, and voluntary sector. She is the Head Department of Social Justice and Administration, Faculty of Arts and Social Sciences. She is an external examiner for Medical Social Work Program, National University of Malaysia and also an active member of Family Development and Research Centre, University of Malaya. She received her $\mathrm{Ph} . \mathrm{D}$. degree from the University of Malaya, Malaysia.

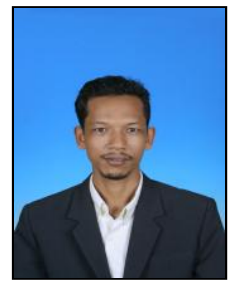

Mohd Awang Idris is a senior lecturer in work psychology, Department of Anthropology and Sociology, University of Malaya, Malaysia. His research interests include job stress, psychosocial safety climate, leadership, job engagement, workplace injuries, and team performance. He publishes several papers in ISI-outlets publications, and also a reviewer for some well-known journals such as Journal Occupational and Organizational Psychology, International Journal of Stress Management, Cross-Cultural Management: An International Journal, and Journal Occupational Health. He received his Ph.D. degree in psychology from the University of South Australia, Adelaide. 